\title{
Rare case of melanoma studied for Its histopathological features in
} Indonesia

\author{
Achmad Tjarta', Mpu Kanoko', Masato Ueda ${ }^{2}$, Mochtar Hamzah ${ }^{3}$, Herman Cipto ${ }^{3}$, Masamitsu Ichihashi ${ }^{2}$, Evert \\ Poetiray ${ }^{4}$, Arman Muchtar ${ }^{4}$, Santoso Cornain ${ }^{1}$, Joedo Prihartono ${ }^{5}$, Setyawati Budiningsih ${ }^{5}$, Yoshiyuki Ohno ${ }^{6}$
}

\begin{abstract}
Abstrak
Banyak parameter histopatologik untuk kepentingan pengelolaan yang optimal dan untuk menentukan prognosis melanoma malignum kulit primer stadium I. Ketebalan tumor, level Clark dan bebasnya tepi sayatan adalah yang paling penting. Laporan pemeriksaan patologi yang baik bergantung pada cara penanganan jaringan biopsi eksisi. Diantara 126 kasus kanker kulit pada penelitian bersama Jepang - Indonesia didapatkan 9 kasus melanoma yang terdiri atas 6 perempuan dan 3 laki - laki. Hanya 5 dari 9 kasus yang dapat di laporkan dalam bentuk laporan histopatologi yang baik sedangkan yang lain tidak absah, oleh karena keterbatasan keterangan, pengelolaan jaringan eksisi tidak benar, atau jaringan yang di peroleh merupakan jaringan hasil biopsi insisi. Kebanyakan kasus berlokasi pada kaki, terutama tumit. Ketebalan rata - rata tumor ialah $7.94 \mathrm{~mm}$.
\end{abstract}

\begin{abstract}
There are many histopathological parameters for optimal management and determining prognosis of stage I primary skin malignant melanoma patients. Tumor thickness, Clark level and tumor free margin are the most important. Excellent pathological report depends on the right procedure of handling and preparing the excisional biopsy. Among 126 skin cancer cases analyzed in Japan - Indonesia joint study, there were 9 cases of malignant melanoma consisted of 6 female and 3 male. Only 5 from 9 cases can be reporting as an excellent diagnosis of pathology, while the others were not valid because of limited information. Wrong handling and preparing biopsies specimens or the specimen was an incisional biopsy tissue. The most frequent tumor site was on foot especially soles. Median tumor thickness was $7.94 \mathrm{~mm}$.
\end{abstract}

Keyword : melanoma, pathological reporting

There are many histolopathological parameters which are important to predict the survival of stage I primary cutaneous malignant melanoma patients, among others ulceration, Clark level, tumor's thickness in millimeters, prognostic index, risk group, post operative histological classification (pTNM), lymphocytic reaction, angioinvassion, microscopic satelitosis and associated with pigmented nevi. Further, immunologic

'Department of Anatomic Pathology, Faculty' of Medicine, University of Indonesia, Jakarta 10430, Indonesia.

- Deparment of Dermatology. Kobe University School of Medicine, Kolse 650-0017. Japan

"Deparmin'me of Dermatology. Faculty of Medicine. University of Indonesia, Jakarta 10430, Indonesia.

Department of Surgery. Faculty of Medicine, University of Indonesia, Jakarta 10430. Indonesia.

'Department of Community Medicine, Faculty of Medicine, University of Indonessia, Jakarta 10320. Indonesia.

" Department of Preventive Medicine, Nagoya University School of Medicine. Nagoya 466.8550, Japan parameters and DNA aneuploidy also influence the prognosis of malignant melanoma patients.

An informative and accurate histophatological report is essential prerequisite for optimal therapy for melanoma. Not all histological parameters have the same accuracy and can be conducted in routine examination. ${ }^{2}$ However, tumor thickness, Clark level, and absolute removal of margins of the lesion are the most important. ${ }^{3}$ Histopathological evaluation on regional lymph nodes is important for planning optimal treatment and determining the prognosis.

Excellent pathological report of melanoma depends on the right procedure of handling and preparing the excisional biopsy specimen, especially in determining tumor thickness according to Breslow method.

The purpose of this paper is to discuss hitopathologic parameters which should be included in pathological report of excisional biopsy specimen of the primary 
malignant malanoma cases encountered in Japan Indonesia joint study of skin cancer.

\section{MATERIALS AND METHODS}

To allow better evaluation of the histopathological features of melanoma, both standard classification and specific guidelines were applied. They included histologic types, depth of tumor cell invasion, tumor thickness, mitotic activity, prognostic index, melanotic nevi association, satellitosis, vascular invasion and ulceration. For clarity, they are respectively described briefly in the followings.

\section{Histologic types of malignant melanoma}

Most cases of malignant melanoma are malignant tumors of epidermal melanocytes. ${ }^{4}$ Based on the clinical characteristic and biological behaviour, it is divided into 4 types, i.e. lentigo malignant melanoma (LMM), superficial spreading melanoma (SSM), nodular melanoma (NM) and acral lentigeneous melanoma (ALM).

The characteristic of LMM and SSM are that they last a long period and a slow horizontal growth, followed by a rapid radial growth. This changes of growth which are characteristic for primary lesion is probably due to one or more strains of cells which have an aggressive biological potential. The primary turnor may. last for a relatively long period of time during which host selective forces act, allowing quite malignant strains of cells to grow. These cells grow to deeper part. Microscopically these cells look like a group of cells which do not contain melanin pigment in their cytoplasm. The group of tumor cells which has the characteristics of aggressiveness might develop at the initial evolution of the primary turnor and will manifest as NM; assuming that this is a tumor which is very malignant from the beginning. ${ }^{3}$

LMM is a flat, brownish colored lesion which grows slowly and usually occurs in the elderly, Microscopically it can be observed that atypical melanocytes in the basal epidermal region at the tumor margin are increasing. Sometimes it forms melanocytes with many nuclei or nests of tumor cells in the disorganized epidermis.

SSM is a lesion which is slightly elevated at the surface of the skin and has a long lasting horizontal growth. Microscopically in the epidermis at the tumor margin, tumor cells are seen scattered in the stratum corneum. In general the tumor cells are separated. Most of the tumor cells have the form of epithelioid cells with abundant cytoplasm, containing delicate melanin pigment granules, large nuclei and nucleoli. Tumor cells are usually monomorphus. Tumor cells progress until more than 3 rete ridges outside the tumor.

NM is a tumor which is or resembles an exophytic growth or polypoid. Microscopically no invasion of tumor cells are found in the epidermis at the margin of the tumor.

Neurotropic melanoma showed infiltration of tumor cells along nerve sheath and angiotropic melanoma showed infiltration of tumor cells along vascular vessels.

Acral lentigeneous melanoma occurs on the palms and soles and on the ungual and periungual regions. The soles being the most common site. ${ }^{5}$

In order to determine the histologic type of malignant melanoma it is essential to take a section from the margin of the tumor on routine histopathological examination.

The depth of tumor cell invasion in cutaneous malignant melanoma

Based on the depth of tumor cell invasion, Clark et al ${ }^{4}$ have divided malignant melanoma into 5 levels, i.e. I, II, Ill, IV and V.

Level I : tumor cells confined to epidermis (in situ)

Level II : tumor cells have penetrated basal membranes and invaded dermal papillae.

Level Ill : tumor cells have already invaded dermal papillae and have reached the boundaries between dermal papillae an reticular dermis.

Level IV : tumor cells have already invaded reticular dermis.

Level V : tumor cells have already invaded subcutaneous tissue.

It is relatively easy to determine the level of tumor cells invasion in cutaneous malignant meianoma in routine histopathological examination. Dermal papillae consist of fine collageneous fibres, while reticular dermis consist of coarse collageneous fibres piled in 
irregular bundles. The border of dermal papillae and reticular dermis can be easily recognized in a specimen stained with Trichrome, i.e. Pico-Mallory, Masson or van Gieson. ${ }^{3}$

\section{Thickness of the tumor}

The Clark's level $\mathrm{V}$ malignant melanoma shows clinical stages I (without metastases) and shows different 5-year survival rates. ${ }^{5,6}$ Besides, it is often difficult objectively to determine whether it is Clark's level I or II malignant melanoma. In this relation, Breslow ${ }^{6}$ suggested to take direct measurement of the depth of tumor invasion by measuring the thickness of the tumor with an ocular millimeter.

The section is made from tumor tissues preserved in neutral formaline solution, by taking tangential section of the central part of the tumor, and stained with $\mathrm{H}$ \& E. In cases of a large tumor several sections are taken. The thickness of the tumor is measured with an ocular millimeter from the top of the granular layer of the epidermis to the lowest point of tumor cells invasion. When the tumor is ulcerated, measurement is taken from the base of the ulcer till the deepest point of tumor cell invasion.

Measurement of tumor thickness is the best method to determine the prognosis of primary cutaneous malignant melanoma compared to determining the depth of invasion according to Clark's method. The possibilities of recurrence might be directly proportional to the thickness of the tumor. ${ }^{6}$ It means that it is important to determine the thickness of the tumor for further management. In patients with tumor thickness not more than $1.50 \mathrm{~mm}$, it is not necessary to dissect the regional lymph nodes. Different institutions have different ways of managing tumor and the regional lymphnodes. ${ }^{7,8}$

For practical reasons measuring the thickness of tumor is more reliable than to determine the level of tumor cells invasion according to Clark's method. However in routine histopathological examination it is recommended always to mention the level of tumor cell invasion besides the thickness of tumor according to Breslow's method. ${ }^{2}$

\section{Mitotic Activity}

The number of mitoses which was found on histologic examination of $\mathrm{MM}$ was directly correlated with prognosis. Ten-year survival of patients with no mitosis or one mitosis noted in a high-power microscopic field was $87 \%$ compared to $64 \%$ for lesions with two or more mitoses per high-power field. ${ }^{1}$

\section{Prognostic index of malignant metanoma}

The prognostic index of malignant melanoma is the result of multiplication of the thickness of the tumor in millimeter on measurement according to Breslow's method with the mitotic rate per square millimeter on the standard of histologic assay. 9,10

In stage I, a more accurate prognosis can be determined by prognostic index rather than the thickness of the tumor, particularly in patients with a tumor thickness of $1.50 \mathrm{~mm}-3.49 \mathrm{~mm}$. When the prognostic index in this group was higher than 19, the death rate would be higher compared to a prognostic index less than $19 .^{10}$

It is obvious that the prognostic index is important in the selection of patients with malignant melanoma who have a poor prognosis and need further treatment, for instance dissection of lymphnodes or immunotherapy. 9,10

Prognostic index can be determined on routine histopathological examination. The thickness of the tumor was measured according to the method of Breslow, i.e. the distance between the top of the granular layer of the epidermis until the lowest point of tumor cells invasion by using an ocular millimeter. The mitotic rate was counted at least in 1.50 square milimeter (10 $\mathrm{HPF}$ ) by using $40 \mathrm{x}$ objectives lens, afterwards converse into 1 square miliimeter. The area of 1 high power field is evaluated through the formula $\eta r^{2}$.

\section{Histologic association with melanocytic nevi}

MM appears to arise histopathogically from a melanocytic ic nevi in approximately $20 \%$ of cases ${ }^{11}$. In the remainder of cases, $\mathrm{MM}$ arise de novo that is from melanocytes not associated with melanocytic nevi. Patients with $\mathrm{MM}$ associated with acquired melanocytic nevi had a better prognosis, i.e. five year survival of $95 \%$ as compared with those having lesions that arose de novo $85 \% .^{11}$ Although no specific reason is yet known for this difference. ${ }^{\text {" }}$ 


\section{Microscopic satellitosis}

These satellitosis were defined as discrete nest of tumor cells at least $0.05 \mathrm{~mm}$ in diameter separated from the main body of the tumor by reticular dermal collagen or subcutaneous fat. The presence of these called "microscopic satellitosis" connotes a poorer orognosis.' Microscopic satellitosis also appear to influence the presence of tumor in regional lymph nodes independent of the tumor thickness and the increased tendency to developed local recurrence. ${ }^{12}$

\section{Vascular invasion}

Vascular invasion protends a poorer prognosis. The observation of a thin lining of endothelium is vital to be certain that a neoplastic cells is in fact within the lumen of a vascular or lymphatic channel. Factor VIII immunoperoxidase staining can often be helpful in defining the nature of tumor cell within vascular channel.'

Table 1. Age distribution of melanoma cases according to sex

\begin{tabular}{ccccc}
\hline Age & Male (s) & Female (s) & Total & $\%$ \\
\hline $30-39$ & 1 & 2 & 3 & 33.4 \\
$40-49$ & 1 & - & 1 & 11.1 \\
$50-59$ & - & 1 & 1 & 11.1 \\
$60-69$ & 1 & 2 & 3 & 33.3 \\
$70-79$ & - & - & - & - \\
$80-89$ & - & 1 & 1 & 11.1 \\
\hline Total & $\mathbf{3}$ & $\mathbf{6}$ & 9 & $\mathbf{1 0 0 . 0}$ \\
\hline
\end{tabular}

The age of patient ranged from 30 to 80 years, which peaked on $30-39$ and $60-69$ years.

\section{Ulceration}

The clinical and histopathological presence of ulceration in a malignant melanoma (MM) is a poor prognostic sign. ${ }^{13}$ Patients with ulcerated lesions had a poorer prognosis compared to those without ulceration. In general ulcerated lessions also tend to be thicker than nonulcerated ones. However, multivariate analysis, has shown the presence of ulceration as significant factor even after the lesion thickness has been taken into account.' It is recomended that the breadth of the ulcer be reported. Ulcer more than 3 $\mathrm{mm}$ in breadth have been associated with poorer prognosis. $^{14}$

\section{RESULTS}

From 126 cases of skin cancer in this study there were 9 cases of malignant melanoma, consisted of 6 females and 3 males. The ratio of the frequency in female to male was 2 tol (Tabel 1).

Table 2. Site distribution of melanoma cases according to sex.

\begin{tabular}{lcccc}
\hline Site & Male (s) & Female (s) & Total & \% \\
\hline Axilla & - & 1 & 1 & 11.1 \\
$\begin{array}{l}\text { Arm : Upper } \\
\text { arm }\end{array}$ & 1 & - & 1 & 11.1 \\
Tumb & - & 1 & 1 & 11.1 \\
Foot & 1 & 1 & 2 & 22.2 \\
Sole & 1 & 2 & 3 & 33.3 \\
Plantar pedis & - & 1 & 1 & 11.1 \\
\hline Total & 3 & $\mathbf{6}$ & $\mathbf{9}$ & $\mathbf{1 0 0 . 0}$ \\
\hline
\end{tabular}

The most frequent of melanoma was on foot, especially sole 
Table 3. Sex, age and site distribution by histological parameters

\begin{tabular}{|c|c|c|c|c|c|c|}
\hline No & Sex & Age & Site & His type & Clark level & Thickness mm \\
\hline 1. & $\mathrm{~F}$ & 69 & foot & ALM & V & 4.3 \\
\hline 2. & $F$ & 80 & Left tumb & ALM & $\mathrm{V}$ & 6.3 \\
\hline 3. & $\mathrm{~F}$ & 60 & Left sole & ALM & V & 15.6 \\
\hline 4. & M & 32 & Righ upper arm & SSM & IV & 4.0 \\
\hline 5. & M & 45 & Righ Foot & $\mathrm{N}$ & IV & 8.5 \\
\hline 6. & $\mathbf{F}$ & 33 & Plantar pedis & $\ldots$ & no data & -..- \\
\hline 7. & F. & 30 & Axilla & \multicolumn{3}{|c|}{$\begin{array}{l}\text { (Procedure of handling and preparing the specimen } \\
\text { is unadequate) }\end{array}$} \\
\hline 8. & $F$ & 54 & Left sole & $\ldots$. & Unadequate data & $\ldots$. \\
\hline 9. & M & 60 & Left sole & $\ldots$ & Biopsy specimen & $\ldots$ \\
\hline
\end{tabular}

Only 5 cases with complete data. Other cases were limited data, or wrong procedure of handling and preparing of specimen and biopsy specimens, or incisional biopsy specimen only. Most cases were ALM type and Clark level V median tumor thickness was $7.944 \mathrm{~mm}$.

\section{DISCUSSION}

The data in this study showed that melanoma cases occurred more often in females compared to males. The previous findings showed that melanoma in Jakarta and also from outside Jakarta occurred more often in males as have been reported by us ${ }^{15}, 16,17,18$ and other investigator. ${ }^{19}$ White people exhibited a wide range of melanoma incidence and females commonly had a higher incidence than males. ${ }^{20,21}$

Non-white people exhibited in general a much lower incidence of melanoma. It has been suggested that skin pigmentation protect against melanoma. ${ }^{21}$ All groups of Africans have a higher incidence of melanoma than any group of Asians. There was a predominance of either sex among these racial groups, although the combined rate for Asian males was nearly twice than of females. ${ }^{2 !}$

In this study the tumors were mostly located at lower extremities, especially on the soles and plantar pedis. This was similar to our previous finding $5,16,17,18$ and other investigator. ${ }^{19}$

It appeared that melanoma were mostly sited at lower extremities, especially on the soles. This is similar to the findings reported among Chinese of Hongkong, 22 Puerto Rican, ${ }^{23}$ Japanese ${ }^{24}$ and Philipines. ${ }^{25}$ Conceming the high frequency of tumor site at the lower extremities many investigators considered its relation to trauma and ultraviolet effect of sunshine. ${ }^{22.23}$ Such factors might also be taken into consideration for our data, since a large proportion of the Indonesian population, especially in rural areas were working in agricultural sectors. They are used to work in traditional ways with naked foot which allows a long time exposure to ultraviolet rays from the sun and trauma on their foot. Also the more frequent occurrence of melanoma on the feet of males from outside Jakarta suggested the possibility of trauma as a contributing risk factor. In contrast, the population of Jakarta was predominantly employed in industrial sectors, wearing shoes. ${ }^{16,18}$

In Israel a higher incidence of melanoma was found among agricultural workers in the Kibbuts than in the city. $^{26}$ The role of trauma associated with walking barefooted had been emphasized as a possible etiologic factor, ${ }^{18,19}$ However, the Chinese of Hong Kong, as shoe-wearing society, a similar result was obtained, i.e. the majority of melanoma occurred on the foot. It was suggested that many physical or chemical agents may be the factor causing changes in this areas. The tumors were most frequently found on the sole, indicating that weight-bearing as a trauma is an important factor. ${ }^{23,27}$

In Uganda it was observed that melanoma on the sole of the feet corresponded with that of discrete of pigment "spot" and the spots were frequent. The physical and chemical agents especially heat and 
wooden smoke may be the factors causing melanoma in this area. ${ }^{28}$

The present study indicated that the growth pattern (histological type) was mainly ALM type (3 case), SSM and NM type is 1 case each. This pattern was different from the result of previous study in the same laboratory. ${ }^{18}$ NM type was the most frequent and only a few cases of LMM and ALM type. No SSM type had been found. However, the pattern was the same as the melanoma among the Chinese of Hong Kong, the tumor were mainly ALM type followed by SSM and NM type. ${ }^{22}$

Among the Caucasians, SSM type was the most frequent, followed by NM, ALM and LMM type. ${ }^{29}$ NM type have a bad prognosis compared to LMM or SSM type. ${ }^{30}$ In New South Wales (Australia) and Alabama (USA) the incidence of NM type has decreased during 25 years (1955-1980), while the incidence of SSM type has increased significantly. ${ }^{31}$

Early studies suggested that different histologic types of MM correlated with prognosis. However, later multivariate analysis did not show histologic type to be of dominant prognostic significance when other values were taken into account.

The difference in survival among these different types of $\mathrm{MM}$ is more probably related to difference in lesion thickness and anatomic site. ${ }^{1}$ The evaluation of the depth of tumor cells invasion (Clark level) revealed that the majority of cases ware level V, followed by level IV. This finding was similar to the result of the previous study that most cases were level V, followed by level IV and level III. ${ }^{16,18}$ This finding seemed to differ from other studies. In New South Wales and Alabama, it was reported that level of invasion have changed. The incidence of melanoma in level II has increased while deeper lesion (level IV) has decreased $^{31}$. The death rate of level II was $8.3 \%$, level III was $35.2 \%$, level IV was $46.1 \%$ and level V was $52 \%{ }^{4}$

Tumor thickness on 5 cases in this study ranged from $4.4 \mathrm{~mm}$ to $15.6 \mathrm{~mm}$ with median thickness $7.94 \mathrm{~mm}$. Previous study in this laboratory, tumor thickness ranged from $2.7 \mathrm{~mm}$ to $20.25 \mathrm{~mm}$ with median thickness $10.52 \mathrm{~mm}$. Comparing to previous study 9 years ago, the present study revealed decreasing tumor thickness which might indicate that the characteristic was moving to better prognosis. Such tendency might be due to the following reasons: 1) increased knowledge of the disease, or 2) increased alertness about the disease, or 3) improvement of socioeconomic status of the people, or 4) improvement of health care facility. Total cases at present study were too small to allow adequate statistical analysis. In this study only 5 from 9 cases of melanoma could be reported as an excellent pathological diagnosis. Four cases could not be analyzed for the histological typing, Clark level and tumor thickness because of limited information or inadequate preparation of the biopsy specimen.

\section{Acknowledgement}

We are grateful to the International Cancer Research Grant system, Monbusho, Japan and the Dean, Faculty of Medicine, University of Indonesia, Jakarta and we would also thank the Director of Dr. Cipto Mangunkusumo National Central General Hospital for technical assistance.

We appreciate the Dean's approval No. 845/PT02.H4.FK/E/97 of the Japan-Indonesia collaborative study. This work has been also supported by the grant no. 09042004, under Ministry of Education, Science, Sport and Culture, Government of Japan and was partly supported by the Indonesian Cancer Foundation, the Jakarta International Cancer Conference Fund and the Terry Fox Foundation, Canada.

\section{REFERENCES}

1. Friedman RJ, Rigel DS, Kopf AW, Haris MH, Baker D. Cancer of the skin. Philadelphia, WB Saunders 1991; $117-$ 98.

2. McGovern VJ, Mihm MG Jr, Baily JC. The classification of malignant melanoma and its histologic reporting. Cancer 1973; 32: 1446-57.

3. Australian Cancer Network. Guidelines for the management of cutaneous melanoma. The Stone Press 20 Hermington St. Epping 2121, June 1997

4. Clark WH, From L Semadio EA, Mihm MC. The histogenesis and biologic behaviour of primary human malignant melanoma of the skin. Cancer Res 1969; 29: 705-14.

5. Lever WF, Lever DS. Histopathology of the skin. Philadelphia $7^{\text {th }}$ ed. Lippincott, 1990: 780-96.

6. Ackerman AB. Disagreements about classification of malignant melanoma. Am J Dermatopathol 1982: 4: 447 52.

7. Breslow A. Thickness, cross-sectional areas and depth of invasion in the prognosis of cutaneous melanoma. Ann Surg 1970; 72: 902-8. 
8. Breslow A. Prognostic factor in the treatment of cutaneous malignant melanoma. J Cutan Pathol 1979; 6: 208-12.

9. Brestow A. Tumor thickness, level of invasion and node dissection in stage 1 cutaneous melanoma. Ann Surg 1975; 182: $572-5$

10. Schmoeckei C, Braun-Falco 0 . Prognostic index in malignant metanoma. Arch Dermatol 1978; 114: 871 - 3 .

11. Kopf AW, Gross DF, Roger GS, Rigei DS, Heliman Li. Levenstein $M$, et al. Prognostic index for malignant melanoma. Cancer 1987; 59: 1236-71.

12. Friedman RJ, Riegel DS, Kopf AW. Favorable prognosis for malignant melanoma associated with acquired melanocytic nevi. Arch Dermatol 1983 ; 119: 455-62.

13. Kelly JW, Sajabiel RW, Calderon W, Murillo L, Dubin RL, Blois MS. The frequency of local recurrence and microsatellites as a guide to re-excision margins for cutaneous malignant melanoma. Ann Surg 1984; 200: 759-63. -

14. McGovern VJ, Shaw HM, Milton GW. Prognostic significance of the histologic feature of malignant melanoma. Histopathology 1979; 3: 385-93.

15. Tjarta A, Kanoko M, Mangunkusumo R. Malignant Melanoma. Pathological aspects of primary cutaneous maligant melanoma. In: Cancer in Asia Pacific. Yayasan Kanker Indonesia, Jakarta, Indonesia : 1988. Vol 2: 997 1003.

16. Tjarta A. The incidence and histopatological aspect of primary skin malignant melanoma in Jakarta, Indonesia. Presented on XIVth International Pigment cell Conference, Kobe October 31-November 4, 1990.

17. Tjarta $A$. The role of histophatological examination on the prognosis of cutaneous maligant melanoma. Indon. J. Oncol 1991; 2: 125-30.

18. Tjarta A. Maligant melanoma of the skin. Some histopathological aspects and its prognostic value. Indon. J. Oncol 1992; 3: 1-6.

19. Pringgoutomo S. Skin Cancer In Indonesia. Natl Cancer Inst Monogr 1963; 10: 191-5.
20. Magnus $\mathrm{K}$. Incidence of malignant melanoma of the skin in Norway, 1955 - 1970. Cancer 1973; 32: 1275-86.

21. Crombie IK. Racial differences in melanoma invidence. $\mathrm{Br}$ J Cancer 1979; 40; 185-93.

22. Colins JR. Melanoma in the Chinese of Hongkong. Emphasis on volar and Subungual Sites. Cancer 1984; 54: 1482-8

23. Pantoja E, Llobet RE, Roswitz B. Melanoma of the lower Extremity among native Puerto Ricans. Cancer 1976; 38 : 1420-3.

24. Seiji M, Takahishi M. Acral melanoma in Japan. Human Pathol 1982; 13 (7): 607-9.

25. Pantangco EE, Canlas M, Basa G, R. Observation on the incidence, biology and pathology of skin cancer among Filipinos. Natl Cancer Inst Monogr 1963; 10: 109-25.

26. Anaise D, Steinitz R, Ben Hur N. Solar radiation a possible etiological factor in malignant melanoma in Israel. Retrospective study (1960 - 1972 ). Cancer 1978; 42: 299304.

27. Hind MW. Anatomical distribution of malignant melanoma of the skin among non- caucasians in Hawaii. Br J Cancer 1979; 40: 497-9.

28. Lewis MG, Kiryabwire JWM. Aspect of behavior and natural history of malignant melanoma in Uganda. Cancer 1986; 21 : 876-87.

29. Lonspari S, Mihnm MC Jr. Clinical and pathological corelation of malignant melanoma. J Cutan Pathol 1979; 6: 180-94.

30. McGovem VJ. Melanoma. Histopathological diagnosis and prognosis. New York: Raven Press, 1982; 158-81.

31. Balch CM, Soong S-J, Milton GW, Shaw HM, McGovern VJ, Mc Carthy WH, et al. Changing trends in cutane malignant melanoma over a quarter century in Alabama, USA and New South Wales, Australia. Cancer, 1983; 52 : 1748-53. 